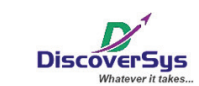

Published by DiscoverSys

\section{Risk factors of stunting for 12-36 month old children in Dasan Agung Public Health Centre, Mataram, West Nusa Tenggara Province}

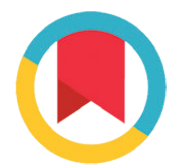

CrossMark

\section{ABSTRACT}

A very high stunting prevalence (37.17\%) was reported in Mataram City, West Nusa Tenggara. Dasan Agung Public Health Centre localed at the centre of Mataram City reports the highest stunting prevalence (27.78\%) in children under 5 year of age. The study design was a cross sectional, using a sample of 158 children aged 12-36 month. The dependent variable was 12-36 month old children displaying stunting and the independent variables were socio-economic status, mother's height, maternal age, mother's level of education, ANC clinic visit frequency and quality of care, birth weight, exclusive breastfeeding, complementary feeding, birth order and main caregiver choice. Data was collected through interviews and anthropometric measurement. The instruments used in collecting the data were RISKEDAS and SUSENAS I modification questionnaires, microtoise and infantometer. Data analysis was conducted in stages that included univariate, bivariate (chi-square) and multivariate (logistic regression). A high prevalence of stunting (48.1\%) was evident. There were six variables in the bivariate test results impacted upon of association. These were socio-economic status $\mathrm{OR}=2.83$ ( $95 \% \mathrm{Cl}$ : $1.35-5.94)$, mother's height $\mathrm{OR}=3.37$ (95\%Cl: 1.69-6.72), ANC clinic visit frequency and quality of care $O R=2.3(95 \% \mathrm{Cl}: 1.21-4.36)$, birth weight $\mathrm{OR}=20.47(95 \% \mathrm{Cl}$ : 1.16-354.25), exclusive breastfeeding $\mathrm{OR}=4.94$ ( $95 \% \mathrm{Cl}$ : 2.51-9.74) and complementary feeding $\mathrm{OR}=6.38(95 \% \mathrm{Cl}: 3.18-12.78)$. The variables of maternal age, mother's level of education, birth order and main caregiver choice were not influencing factors. In the multivariate analysis, the dominant variables increasing risk factors was complementary feeding giving $\mathrm{OR}=7.4(95 \% \mathrm{Cl}$ : $1.54-34.97)$, mother's height $\mathrm{OR}=2.9$ (95\% $\mathrm{Cl}: 1.27-6.42)$ and $\mathrm{ANC}$ clinic visit frequency and quality of care $O R=2.4(95 \% \mathrm{Cl}: 1.09-5.19)$. It is recommended that there be efforts to improve the nutrition intake of young girls, women of productive age, pregnant women and children under five years old.

\title{
Faktor risiko balita stunting usia 12-36 bulan di Puskesmas Dasan Agung, Mataram, Provinsi Nusa Tenggara Barat
}

\section{ABSTRAK}

${ }^{1}$ Public Health Postgraduate Program Udayana University, ${ }^{2}$ School of Public Health Udayana University,

${ }^{3}$ Community and Preventive Medicine Department Faculty of Medicine Udayana University, ${ }^{4}$ Mataram Health Polytechnic

*Correspondence to: Imtihanatun Najahah, Public Health Postgraduate Program Udayana University, Mataram Health Polytechnic imti01@yahoo.co.id
Prevalensi stunting di Kota Mataram, Provinsi NTB sebesar 37,17\%. Salah satu puskesmas yang ada di Kota Mataram adalah Puskesmas Dasan Agung memiliki prevalensi balita stunting sebesar 27,28\%, sehingga perlu dikaji faktor risiko balita stunting usia 12-36 bulan di Puskesmas Dasan Agung. Desain penelitian adalah cross sectional, dengan besar sampel 158 balita. Variabel terikat dalam penelitian ini adalah balita stunting dan variabel bebas adalah status sosial ekonomi, tinggi badan ibu, usia pertama ibu menikah, tingkat pendidikan ibu, kunjungan ANC, berat badan lahir, ASI eksklusif, pemberian MPASI, urutan anak dan pengasuh anak. Data dikumpulkan dengan wawancara dan pengukuran antropometri. Instrumen yang digunakan modifikasi kuesioner RISKESDAS dan SUSENAS I ibu hamil, microtoise dan infantometer. Analisis data dilakukan secara bertahap meliputi analisis univariat, bivariat (chi-square) dan multivariat (regresilogistik). Prevalensi balita stunting 48,1\%. Dari hasil uji bivariat ada enam variabel yang meningkatkan faktor risiko yaitu status sosial ekonomi $\mathrm{OR}=2,83$ (95\%Cl: 1,355,94), tinggi badan ibu $0 \mathrm{R}=3,37(95 \% \mathrm{Cl}: 1,69-6,72)$, kunjungan ANC $0 \mathrm{R}=2,3 \quad(95 \% \mathrm{Cl}: 1,21-4,36)$, berat badan lahir $0 \mathrm{R}=20,47$ (95\%Cl: 1,16-354,25), ASI eksklusif OR=4,94 (95\%Cl: 2,51-9,74) dan pemberian MPASI OR=6,38 (95\% Cl: 3,18-12,78), sedangkan variabel usia pertama ibu menikah, tingkat pendidikan ibu, urutan anak dan pengasuh anak tidak terbukti meningkatkan fakor risiko. Pada analisis multivariat variabel yang dominan adalah pemberian MPASI $0 R=7,4$ (95\%Cl: 1,54-34,97), tinggi badan ibu OR=2,9 (95\%Cl: 1,27-6,42) dan kunjungan ANC OR=2,4 (95\%Cl: 1,09-5,19). Perlu dilakukan upaya pencegahan melalui perbaikan asupan gizi mulai dari remaja putri, wanita usia subur, ibu hamil maupun pada balita. 
Kata kunci: balita stunting, cross sectional, Mataram

Kutip artikel ini: Najahah, I., Adhi, K.T., Pinatih, G.N.I. 2013. Faktor risiko balita stunting usia 12-36 bulan di Puskesmas Dasan Agung, Mataram, Provinsi Nusa Tenggara Barat. Public Health and Preventive Medicine Archive 1(2): 103-108. D0I:10.15562/phpma.v1i2.171

\section{PENDAHULUAN}

Stunting adalah keadaan tinggi badan menurut umur $(\mathrm{TB} / \mathrm{U})$ pada anak balita berada di bawah -2SD berdasarkan pengukuran antropometri. Stunting mengindikasikan masalah gizi kronis sebagai akibat dari keadaan yang berlangsung lama, misalnya: kemiskinan dan pola asuh atau pemberian makanan yang kurang baik dari sejak anak dilahirkan yang mengakibatkan anak menjadi pendek. ${ }^{1,2}$ Secara nasional sudah terjadi penurunan prevalensi balita stunting yaitu pada tahun 2007 sebesar $36,7 \%$ menjadi $35,7 \%$ pada tahun $2010 .{ }^{3}$

Di Provinsi NTB secara spesifik terjadi peningkatan jumlah prevalensi balita stunting dari tahun 2009 (38,91\%) ke tahun $2010(42,63 \%) .{ }^{4}$ Kota Mataram merupakan salah satu kota di Provinsi NTB dengan prevalensi balita stunting meningkat dari tahun 2009 sebesar 34,84\% dan meningkat pada tahun 2010 menjadi 37,17\%. ${ }^{4}$ Kecamatan Selaparang merupakan salah satu kecamatan yang berada di Kota Mataram yang memiliki prevalensi balita stunting sebesar $31,22 \% .^{5}$ Salah satu puskesmas yang berada di Kecamatan Selaparang adalah Puskesmas Dasan Agung yang memiliki prevalensi balita stunting sebesar $27,28 \%$ pada tahun $2012 .{ }^{6}$ Berdasarkan data register posyandu tahun 2012 di wilayah kerja Puskesmas Dasan Agung prevalensi balita stunting usia 12-36 bulan sebesar $19 \%$.

Dampak dari stunting ini adalah tidak hanya pada fisik yang lebih pendek, tetapi juga pada fungsi kognitifnya. ${ }^{1}$ Besarnya dampak yang ditimbulkan dari balita stunting dan masih tingginya balita stunting di Kota Mataram, maka dilakukan penelitian tentang faktor risiko balita stunting usia 12-36 bulan di Kota Mataram khususnya di wilayah kerja Puskesmas Dasan Agung.

\section{METODE}

Desain penelitian adalah cross sectional, dilaksanakan sejak Februari-April 2013. Sampel penelitian berjumlah 158 balita berusia 12-36 bulan, berdomisili di wilayah kerja Puskesmas Dasan Agung dan tercatat di register posyandu. Pengambilan sampel dilakukan di tiga kelurahan yang berada di wilayah kerja Puskesmas Dasan Agung. Selanjutnya dari masing-masing kelurahan diambil sejumlah sampel sesuai dengan proporsi jumlah populasi di masing-masing kelurahan.
Didapatkan jumlah sampel di Kelurahan Dasan Agung sebesar 102 balita, Kelurahan Dasan Agung Baru sebesar 36 balita dan Kelurahan Gomong sebesar 20 balita. Pengambilan sampel dilakukan secara simple random sampling. Sampel dieksklusi apabila balita dengan riwayat lahir kembar dan menderita penyakit kronis. Responden penelitian ini adalah ibu dari sampel.

Variabel yang diukur adalah balita stunting usia 12-36 bulan sebagai variabel terikat, sedangkan status sosial ekonomi, tinggi badan ibu, usia ibu pertama menikah, pendidikan ibu, kunjungan antenatal care (ANC), berat badan lahir, pemberian ASI eksklusif, pemberian makanan pendamping air susu ibu (MPASI), urutan anak dan pengasuh anak sebagai variabel bebas.

Pengumpulan data dilakukan dengan wawancara dan pengukuran. Wawancara menggunakan modifikasi kuesioner dari Riset Kesehatan Dasar (Riskesdas) $^{7}$ dan Survei Sosial Ekonomi Nasional (Susenas) I ibu hamil ${ }^{8}$ untuk menggali faktor risiko balita stunting meliputi; status sosial ekonomi, usia pertama ibu menikah, tingkat pendidikan ibu, kunjungan $A N C$, berat badan lahir, ASI eksklusif, pemberian MPASI, urutan anak dan pengasuh anak. Tinggi badan ibu dan balita usia 25-36 bulan diukur dengan menggunakan microtoice dan panjang badan balita usia 12-24 bulan menggunakan infantometer. Penilaian $z$-score panjang badan dan tinggi badan balita dihitung dengan menggunakan software WHO Antro 2005.

Pada penelitian ini balita stunting adalah balita yang memiliki nilai $z$-score untuk indeks panjang badan/tinggi badan (PB/TB) menurut umur <-2SD. ${ }^{9}$ Status sosial ekonomi adalah kemampuan keluarga untuk memenuhi kebutuhan sandang, pangan dan papan anggota keluarga yang dinilai berdasarkan pada garis kemiskinan Provinsi Nusa Tenggara Barat daerah kota (Rp 270.652,- pengeluaran perorang/ bulan). ${ }^{10}$ Tinggi badan ibu adalah tinggi badan ibu yang diukur dengan pengukur tinggi badan microtoise dengan tingkat ketelitian $0,1 \mathrm{~cm}$ dengan standar penilaian $150 \mathrm{~cm} .{ }^{11}$ Kunjungan ANC adalah frekuensi kunjungan ibu hamil untuk memeriksakan kehamilannya pada petugas kesehatan dengan jumlah kunjungan minimal 4 (empat) kali selama kehamilan dengan distribusi kunjungan pada trimester I sebanyak satu kali, trimester II sebanyak satu kali dan trimester III sebanyak dua kali dan mendapatkan pelayanan minimal pemeriksaan kehamilan. ${ }^{9}$ 12 Pemberian MPASI adalah jenis 
makanan yang diberikan kepada bayi selain ASI. Penilaiannya berdasarkan pemberian MPASI pada usia bayi $\geq 6$ bulan atau jenis makanan yang didapatkan adalah makanan lumat. ${ }^{13}$

Analisis data dilakukan dengan univariat untuk melihat distribusi frekuensi dari masing-masing variabel, dilanjutkan dengan analisis bivariat untuk melihat hubungan antara variabel terikat dengan masing-masing variabel bebas, uji hubungan ini digunakan uji chi square. Sedangkan analisis multivariat dengan menggunakan uji regresi logistik metode enter untuk mencari faktor risiko yang dominan meningkatkan risiko balita stunting dilakukan terhadap variabel dengan nilai $\mathrm{p}<0,25$ dari hasil analisis bivariat.
Penelitian ini mendapatkan kelaikan etik dari Komisi Etik Penelitian Fakultas Kedokteran Universitas Udayana/Rumah Sakit Umum Pusat Sanglah Denpasar.

\section{HASIL}

Semua balita usia $12-36$ bulan yang terpilih sebagai sampel dan responden dapat berpartisipasi dan tidak ada yang menolak. Karakteristik sampel sebagian berjenis kelamin perempuan (51,9\%) dengan status gizi berdasarkan $\mathrm{PB} / \mathrm{TB}$ per umur normal (51,9\%), berat badan lahir normal (94,9\%), ASI eksklusif (54,4\%), pemberian MPASI sesuai $(58,9 \%)$ dan urutan anak ke-1 $(53,2 \%)$. Karakteristik

Tabel 1 Crude PR penelusuran faktor risiko balita stunting usia 12-36 bulan di wilayah kerja Puskesmas Dasan Agung

\begin{tabular}{|c|c|c|c|c|c|}
\hline Variabel & $\begin{array}{c}\text { Stunting } \\
(n=76)\end{array}$ & $\begin{array}{c}\text { Normal } \\
(\mathrm{n}=\mathbf{8 2}\end{array}$ & PR & $95 \% \mathrm{Cl}$ & Nilai p \\
\hline \multicolumn{6}{|l|}{ Status sosial ekonomi } \\
\hline Rendah & $28(66,7)$ & $14(33,3)$ & 2,83 & $1,35-5,94$ & 0,005 \\
\hline Cukup & $48(41,4)$ & $68(58,6)$ & & & \\
\hline \multicolumn{6}{|l|}{ Tinggi badan ibu } \\
\hline Pendek & $37(67,3)$ & $18(32,7)$ & 3,37 & $1,69-6,72$ & 0,000 \\
\hline Normal & $39(37,9)$ & $64(62,1)$ & & & \\
\hline \multicolumn{6}{|l|}{ Usia ibu pertama menikah } \\
\hline$<20$ tahun & $21(56,8)$ & $16(43,2)$ & 1,57 & $0,75-3,30$ & 0,229 \\
\hline$\geq 20$ tahun & $55(45,5)$ & $66(54,5)$ & & & \\
\hline \multicolumn{6}{|l|}{ Tingkat pendidikan ibu } \\
\hline Rendah & $40(54,1)$ & $34(45,9)$ & 1,56 & $0,83-2,94$ & 0,160 \\
\hline Tinggi & $36(42,9)$ & $48(57,1)$ & & & \\
\hline \multicolumn{6}{|l|}{ Kunjungan ANC } \\
\hline Tidak standar & $48(57,8)$ & $35(42,2)$ & 2,30 & $1,21-4,36$ & 0,010 \\
\hline Standar & $28(37,3)$ & $47(62,7)$ & & & \\
\hline \multicolumn{6}{|l|}{ Berat badan lahir } \\
\hline Berat badan lahir rendah & $8(100)$ & $0(0,00)$ & 20,47 & $1,16-354,25$ & 0,003 \\
\hline Normal & $68(45,3)$ & $82(54,7)$ & & & \\
\hline \multicolumn{6}{|l|}{ ASI eksklusif } \\
\hline Tidak & $49(69,0)$ & $22(31,0)$ & 4,94 & $2,51-9,74$ & 0,000 \\
\hline Ya & $27(31,0)$ & $60(69,0)$ & & & \\
\hline \multicolumn{6}{|l|}{ Pemberian MPASI } \\
\hline Tidak sesuai & $56(69,1)$ & $25(30,9)$ & 6,38 & $3,18-12,78$ & 0,000 \\
\hline Sesuai & $20(26,0)$ & $57(74,0)$ & & & \\
\hline \multicolumn{6}{|l|}{ Urutan anak } \\
\hline Anak ke- $\geq 2$ & $37(50,0)$ & $37(50,0)$ & 1,15 & $0,61-2,15$ & 0,650 \\
\hline Anak ke-1 & $39(46,4)$ & $45(53,6)$ & & & \\
\hline \multicolumn{6}{|l|}{ Pengasuh anak } \\
\hline Bukan ibu & $14(45,2)$ & $17(54,8)$ & 0,86 & $0,39-1,89$ & 0,710 \\
\hline $\mathrm{Ibu}$ & $62(48,8)$ & $65(51,2)$ & & & \\
\hline
\end{tabular}


Tabel 2 Adjusted PR faktor risiko balita stunting usia 12-36 bulan di wilayah kerja Puskesmas Dasan Agung

\begin{tabular}{lcccc}
\hline & & & \multicolumn{2}{c}{$\mathbf{9 5 \%} \mathbf{C l}$} \\
\cline { 4 - 5 } Variabel Bebas & PR & Nilai p & Batas bawah & Batas atas \\
\hline Tinggi badan ibu & 2,85 & 0,011 & 1,27 & 6,42 \\
Kunjungan ANC & 2,39 & 0,028 & 1,09 & 5,19 \\
Pemberian MPASI & 7,35 & 0,012 & 1,54 & 34,97 \\
\hline
\end{tabular}

$\mathrm{R}^{2}=0,405$

responden; tinggi badan normal $(65,2 \%)$, usia ibu pertama menikah $\geq 20$ tahun (76,6\%), kunjungan ANC tidak standar (52,5\%) dan tingkat pendidikan tinggi $(53,2 \%)$, status sosial ekonomi cukup $(73,4 \%)$ dan pengasuh anak ibu kandung $(80,4 \%)$.

Hasil analisis bivariat ada enam variabel yang berperan meningkatkan risiko balita stunting yaitu status sosial ekonomi, tinggi badan ibu, kunjungan ANC, berat badan lahir, ASI eksklusif dan pemberian MPASI sebagaimana tersaji pada Tabel 1. Balita yang berada pada keluarga dengan status sosial ekonomi rendah berisiko 2,8 kali menderita stunting dibandingkan balita yang berada pada keluarga dengan status sosial ekonomi cukup. Ibu dengan tinggi badan pendek berisiko memiliki balita stunting 3,3 kali dibandingkan ibu dengan tinggi badan normal. Ibu yang melakukan kunjungan ANC tidak standar berisiko memiliki balita stunting 2,3 kali dibandingkan ibu yang melakukan kunjungan ANC standar. Balita dengan berat badan lahir rendah memiliki risiko 20,5 kali mengalami stunting dibandingkan balita dengan berat badan lahir normal.

Balita tanpa ASI eksklusif memiliki risiko 4,9 kali mengalami stunting dibandingkan balita dengan ASI eksklusif. Balita yang mendapatkan MPASI tidak sesuai memiliki risiko 6,3 kali dibandingkan balita yang mendapatkan MPASI sesuai. Sedangkan variabel usia pertama ibu menikah, tingkat pendidikan ibu, urutan anak dan pengasuh anak merupakan faktor yang tidak meningkatkan risiko balita stunting.

Dari analisis bivariat ada delapan variabel yang memiliki nilai $\mathrm{p}<0,25$, selanjutnya dianalisis secara multivariat, dengan hasil seperti pada Tabel 2. Variabel yang berperan dominan meningkatkan risiko stunting balita usia 12-36 bulan di wilayah kerja Puskesmas Dasan Agung adalah tinggi badan ibu, kunjungan ANC dan pemberian MPASI. Ketiga variabel ini berperan terhadap kejadian balita stunting sebesar $40 \%$.

\section{DISKUSI}

Pada penelitian ini tinggi badan ibu, kunjungan ANC dan pemberian MPASI adalah faktor risiko balita stunting. Tinggi badan ibu merupakan faktor internal (genetik) pada ibu yang berperan dalam pertumbuhan anak. Hal ini disebabkan karena genetik merupakan modal dasar dalam mencapai hasil akhir tumbuh kembang anak, melalui instruksi genetik yang terkandung di dalam sel telur yang telah dibuahi, dapat ditentukan kualitas/kuantitas pertumbuhan anak. ${ }^{14}$ Pada penelitian ini, ibu yang pendek berisiko memiliki balita stunting 2,9 kali dibandingkan ibu dengan tinggi badan normal.

Hasil penelitian ini sesuai dengan penelitian yang dilakukan di Meksiko pada tahun 1999 menunjukkan hasil crude analysis didapatkan ibu dengan tinggi badan pendek $(<145 \mathrm{~cm})$ secara signifikan memiliki balita stunting dengan nilai $\mathrm{OR}=4,0$ (95\%CI: 3,2-4,8; $\mathrm{p}<0,001)$ dan dari analisis multivariat dengan regresi logistik didapatkan nilai OR=2,0 (95\%CI: 1,6-2,6; $p<0,001) .{ }^{15}$ Penelitian ini diperkuat juga oleh penelitian di Indonesia yang menunjukkan bahwa prevalensi anak pendek di Indonesia pada ibu dengan rata-rata tinggi badan $<150 \mathrm{~cm}$ lebih tinggi yaitu $47,2 \%$ dibandingkan ibu dengan rata-rata tinggi badan $>150 \mathrm{~cm}$ yaitu sebesar 36,0\%. ${ }^{11}$ Hasil penelitian ini tidak sesuai dengan penelitian di Provinsi Limpopo, Afrika Utara pada tahun 2005 yang menunjukkan bahwa prevalensi stunting pada anak berkulit hitam usia 3 tahun sebesar $48 \%$ dan secara signifikan ibu yang memiliki anak stunting adalah lebih pendek dibandingkan ibu yang memiliki anak tidak stunting dengan nilai $\mathrm{p}=0,006$ dan setelah dilakukan analisis multivariat dengan analisis regresi logistik didapatkan nilai OR=0,6 $(95 \% \mathrm{CI}$ : $0,24-4,35) .{ }^{16}$ Tinggi badan ibu tidak hanya terjadi karena faktor genetik saja akan tetapi terjadi karena ibu mengalami riwayat gizi kurang dalam jangka waktu lama dan kemungkinan ibu mengalami riwayat intra uterine growth retardation (IUGR). ${ }^{16}$ Bila orang tua pendek akibat kekurangan zat gizi atau penyakit, kemungkinan anak dapat tumbuh dengan tinggi badan normal selama anak tidak terpapar faktor risiko lain. ${ }^{17}$ Melihat pentingnya peranan tinggi badan ibu terhadap balita stunting maka sangat penting melakukan pencegahan generasi penerus yang stunting yaitu melalui upaya asupan nutrisi yang cukup bagi masyarakat terutama masyarakat wanita mulai dari sebelum wanita tersebut hamil. 
Kunjungan ANC merupakan faktor risiko balita stunting di wilayah kerja Puskesmas Dasan Agung. Kunjungan ANC yang dilakukan secara teratur dapat mendeteksi dini risiko kehamilan yang ada pada seorang $\mathrm{ibu}^{18}$ terutama yang berkaitan dengan masalah nutrisinya. Pada penelitian ini ditemukan bahwa ibu yang melakukan kunjungan ANC tidak standar memiliki risiko mempunyai balita stunting 2,4 kali dibandingkan ibu yang melakukan kunjungan ANC standar. Kunjungan ANC tidak standar dilihat dari masih ada ibu yang datang memeriksakan kehamilannya ke petugas kesehatan setelah usia kehamilan empat bulan dan tujuh bulan.

Jenis pelayanan ANC pada kunjungan tidak standar yang tidak didapatkan ibu selama kehamilan adalah pemeriksaan tinggi badan dan pemeriksaan darah (hemoglobin). Penelitian ini sesuai dengan penelitian yang dilakukan di RSUD Banyumas yang menunjukkan bahwa ibu yang memiliki kualitas pelayanan antenatal yang kurang baik mempunyai peluang melahirkan bayi dengan berat badan lahir rendah (BBLR) 5,85 kali dibandingkan ibu yang memiliki kualitas pelayanan antenatal baik karena BBLR merupakan faktor yang berperan dalam kejadian stunting. ${ }^{19}$ Melihat pentingnya kunjungan ANC terhadap balita stunting maka diharapkan masyarakat terutama ibu hamil agar memanfaatkan fasilitas pemeriksaan kehamilan semaksimal mungkin agar permasalahan kehamilan terutama yang berhubungan dengan permasalahan nutrisi dapat diketahui sejak awal sehingga dapat dilakukan intervensi lebih awal untuk mengatasi permasalahan tersebut.

Pemberian MPASI merupakan faktor risiko balita stunting di wilayah kerja Puskesmas Dasan Agung. MPASI merupakan makanan yang diberikan kepada bayi/anak disamping ASI untuk memenuhi kebutuhan gizinya. $^{20}$ Pemberian MPASI harus dimulai saat bayi usia enam bulan karena sebelum usia enam bulan, sistem kekebalan usus dan enzim pencernaan bayi belum sempurna sehingga bayi belum dapat mencerna zat tepung dan protein. ${ }^{13} \mathrm{Pada}$ penelitian ini balita yang mendapatkan MPASI tidak sesuai memiliki risiko 7,4 kali mengalami stunting dibanding balita yang mendapat MPASI sesuai. Di wilayah penelitian pemberian MPASI tidak sesuai terjadi karena ibu memberikan MPASI sebelum balita berusia enam bulan. Sebanyak 30 orang yang sudah memberikan MPASI pada saat bayi baru lahir dan dari 30 ibu tersebut 50\% memberikan madu ketika bayi baru lahir. Jenis prelakteal yang diberikan selain madu yaitu teh MPASI yang tidak sesuai terjadi karena ada beberapa balita yang diberikan MPASI berupa jenis makanan lunak (nasi tim atau bubur beras) yang seharusnya didapatkan pada usia ini adalah jenis makanan lumat (bubur susu).
Hasil penelitian ini sejalan dengan penelitian yang dilakukan di Kelurahan Babakan Surabaya, Kecamatan Kiaracondong Bandung pada tahun 2009 yang melaporkan bahwa terdapat pengaruh yang bermakna pemberian MPASI terhadap pencegahan kejadian stunting pada balita usia 24-36 tahun. ${ }^{21}$ Penelitian lain memperlihatkan bahwa $50 \%$ anak sudah diperkenalkan makanan padat pada usia $<6$ bulan dan bayi yang diberikan makanan padat pada usia $<6$ bulan sebanyak $49,4 \%$ mengalami stunting dengan nilai crude $O R=1,17$ (95\%CI: 0,62-2,20). ${ }^{22}$ Penilaian pemberian MPASI pada penelitian di Kenya tersebut hanya melihat dari sisi waktu atau usia balita mulai diberikan MPASI tanpa menilai jenis MPASI yang diberikan. Karena pemberian MPASI sangat penting bagi pertumbuhan bayi, maka masyarakat terutama ibu agar memberikan atau mulai memperkenalkan makanan pendamping ASI mulai usia enam bulan dan memberikan jenis makanan yang sesuai dengan pertambahan umur balita agar kebutuhan nutrisi balita terpenuhi sesuai kebutuhan.

Pada penelitian ini setelah dilakukan analisis multivariat, status sosial ekonomi memiliki nilai $\mathrm{PR}=1,83$; $(95 \% \mathrm{CI}: 0,75-4,47)$ yang berarti bahwa status sosial ekonomi bukan merupakan faktor risiko dari balita stunting. Hal ini kemungkinan karena status sosial ekonomi atau kemiskinan merupakan akar permasalahan dari masalah gizi balita akan tetapi bukan merupakan penyebab langsung dari masalah gizi. ${ }^{23}$ Penelitian ini sejalan dengan penelitian yang dilakukan di Meksiko yang menunjukkan bahwa terdapat hubungan signifikan antara status sosial ekonomi (pendapatan perkapita per bulan) dengan balita stunting di daerah perkotaan pada hasil analisis bivariat, akan tetapi setelah dilakukan analisis multivariat ditemukan tidak ada hubungan yang signifikan. ${ }^{24}$

Pada penelitian ini setelah dilakukan analisis multivariat, berat badan lahir rendah bukan merupakan faktor risiko pada populasi. Bayi yang lahir dengan berat badan lahir rendah karena prematur akan tumbuh dengan baik bila berada di lingkungan optimal. ${ }^{25}$ Penelitian ini sejalan dengan penelitian yang dilakukan di Kecamatan Pati pada tahun 2012, menunjukkan hasil bahwa berat badan lahir rendah bukan merupakan faktor risiko balita stunting dengan nilai $\mathrm{p}=0,112 .{ }^{26}$

Pada penelitian ini setelah dilakukan analisis multivariat, ASI eksklusif tidak berperan sebagai faktor risiko balita stunting pada populasi ditandai dengan nilai $\mathrm{PR}=0,67 ; \quad(95 \% \mathrm{CI}$ : 0,14-3,22). Masa windows critical (masa perkembangan otak atau kecerdasan dan pertumbuhan badan yang cepat pada anak) terjadi sampai usia dua tahun ${ }^{27}$ dan faktor langsung dari masalah gizi adalah asupan nutrisi 
yang dikonsumsi oleh anak ${ }^{23}$ sehingga apabila balita mendapatkan asupan nutrisi yang cukup sesuai dengan kebutuhan walaupun bayi tidak mendapatkan ASI eksklusif maka anak dapat tumbuh dengan baik.

Keterbatasan penelitian ini adalah adanya beberapa item pertanyaan kuesioner yang berisi riwayat dari balita yang kejadiannya sudah berlangsung antara satu sampai dua tahun yang lalu dan pengambilan data diambil dalam sekali waktu sehingga dapat menimbulkan bias.

\section{SIMPULAN}

Faktor pemberian MPASI, tinggi badan ibu dan kunjungan ANC merupakan faktor yang berperan dalam kejadian balita stunting. Untuk menurunkan kejadian stunting pada balita perlu dilakukan upaya pencegahan melalui perbaikan asupan gizi mulai dari remaja putri, wanita usia subur, ibu hamil dan balita.

\section{UCAPAN TERIMA KASIH}

Ucapan terima kasih penulis sampaikan kepada Kepala Dinas Kesehatan Kota Mataram dan pihak yang telah membantu pelaksanaan penelitian ini. Ucapan terima kasih juga penulis sampaikan kepada semua rekan yang membantu terselesainya penelitian ini.

\section{DAFTAR PUSTAKA}

1. Gibney JM, Margetts BM, Kearney JM \& Arab L. Gizi Kesehatan Masyarakat, (Andry Hartono, Pentj), Jakarta: EGC; 2009.

2. Kemenkes RI. Profil Kesehatan Indonesia 2010. Jakarta: Kementrian Kesehatan RI; 2010.

3. Kemenkes RI. Laporan Nasional Riset Kesehatan Dasar (Riskesdas). Jakarta: Badan Penelitian dan Pengembangangan Kesehatan Dasar; 2010.

4. Dikes Provinsi NTB. Laporan Pelaksanaan Pemantauan Status Gizi Keluarga Sadar Gizi. Dinas Kesehatan Provinsi Nusa Tenggara Barat; 2010.

5. Dikes Kota Mataram. Laporan Kesga Dinas Kesehatan Kota Mataram 2011. Dinas Kesehatan Kota Mataram; 2011.

6. Dikes Kota Mataram. Laporan Pekan Penimbangan 2012. Dinas Kesehatan Kota Mataram; 2012.

7. Kemenkes RI. Kuesioner Individu Riskesdas 2010. Jakarta: Badan Penelitian dan Pengembangan Kesehatan Kemenkes RI; 2010

8. Depkes RI. Kuesioner Ibu Hamil - Surkenas I. Jakarta: Badan Penelitian dan Pengembangan Kesehatan Depkes RI; 2001

9. Sedyaningsih ER. Kepmenkes RI nomor: 1995/Menkes/ SK/XII/2010 tentang Standar Antropometri Penilaian Status Gizi Anak. Kemenkes RI Direktorat Jendral Bina Gizi dan Kesehatan Ibu dan Anak Direktorat Bina Gizi; 2011

10. BPS. Jumlah dan persentase penduduk miskin, garis kemiskinan, indeks kedalaman kemiskinan (P1), dan indeks keparahan kemiskinan (P2) menurut provinsi, Maret 2012. BPS. [serial online] 2012 (5 Januari 2013). Available from: URL: http://www.bps.go.id/tabsub/view. php?kat=1\&tabel=1\&daftar=1\&id subyek=23\&notab=1.
11. Atmarita. Masalah anak pendek di Indonesia dan implikasinya terhadap kemajuan negara. Pusat Penelitian dan Pengembangan Ekologi dan Status Kesehatan Badan Penelitian dan Pengembangan Kesehatan, Kemenkes RI; 2010.

12. Mochtar R. Sinopsis Obstetri Jilid 1. Edisi 3, Jakarta: EGC; 2012.

13. Satyawati. MPASI-makanan pendamping ASI dapur ibu. Jakarta: Dian Rakyat; 2012.

14. Soetjiningsih. Tumbuh Kembang Anak. Jakarta: Penerbit Buku Kedokteran Anak; 1998.

15. Hernandez-Diaz S, Peterson KE, Dixit S, Her nandez B,Parra S, Barquera S, et al. Association of maternal short stature with stunting in Mexican children: common genes vs common environment. European Journal of Clinical Nutrition 1999; 53: 938-45.

16. Mamabolo LR, Alberts M, Steyn NP, Henriette ADW and Naomi SL. Prevalence and determinants of stunting and over weight in 3-year-old black South African children residing in the Central Region of Limpopo Province, South Africa. Public Health Nutrition 2005; 8(5), 501-508. DOI: 10.1079/PHN2005786.

17. Amigo H, Buston P, Radrigan ME. Is there a relationship between parent's short height and their children's? Social interclass epidemiologic study. Rev Med Chil 1997 Aug; 125(8).

18. Hofmeyr GJ, Neilson JP, Alfirefic Z, Crowther CA, Duley L, Gulmezoglu M, et al. A cochrane pocketbook pregnancy and childbirth. England: Wiley Cochrane Series; 2008.

19. Sistiarani, C. Faktor maternal dan kualitas pelayanan antenatal yang berisiko terhadap kejadian berat badan lahir rendah (BBLR): Studi pada ibu yang periksa hamil ke tenaga kesehatan dan melahirkan di RSUD Banyumas tahun 2008 [tesis]. Semarang: Fakultas Kesehatan Masyarakat Universitas Diponogoro; 2008.

20. Indiarti MT. ASI, susu formula dan makanan bayi. Yogyakarta: Elmatera; 2008.

21. Djaiz J. Hubungan antara asuhan makan bayi dan pertumbuhan anak pada usia 2 tahun di daerah Kelurahan Babakan Surabaya, Kecamatan Kiaracondong Bandung. Bandung: Bagian Ilmu Kesehatan Anak Fakultas Kedokteran Universitas Padjadjaran/Rumah Sakit Hasan Sadikin; 2009.

22. Bloss E, Wainaina F \& Bailey RC. Prevalence and predictors of underweight, stunting, and wasting among children aged 5 and under in Western Kenya. School of Public Health and Tropical Medicine, Tulane University, New Orleans, LA, USA. Journal of Tropical Pediatrics 2004 Vol. 50, No. 5. Oxford University Press 2004; all rights Reserved.

23. Atmarita \& Fallah ST. Analisis situasi gizi dan kesehatan masyarakat. Widyakarya Nasional Pangan dan Gizi VIII. Jakarta 17-19 Mei 2004.

24. Reyes H, Cuevas RP, Sandoval A, Castillo R, Santos JI, Doubova $\mathrm{S}$ and Gutierres $\mathrm{G}$. The family as a determinant of stunting in children living in conditions of extreme poverty: a case-control study. BMC Public Health 2004, 4:57 doi: 10.1186/1471-2458-4-57.

25. Kusharisupeni. Growth faltering pada bayi di Kabupaten Indramayu Jawa Barat. Makara Kesehatan 2002 Juni; 6(1).

26. Anugraheni HS dan Kartasurya MI. Faktor risiko kejadian Stunting pada anak usia 12-36 bulan di Kecamatan Pati, Kabupaten Pati. Journal of Nutrition College 2012; 1(1): 590-605.

27. Johnson $M$ and Brookstone. Nutrition in the first 1,000 days state of the World's Mothers 2012. Save The Children; 2012.

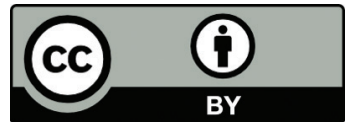

This work is licensed under a Creative Commons Attribution 